\title{
Monika Przybylska
}

Uniwersytet Wrocławski

e-mail: monika_przybylska@o2.pl

ORCID 0000-0001-6552-636X

\section{PRZETARG PUBLICZNY JAKO FORMA WYBORU DOSTAWCY ENERGII ELEKTRYCZNEJ DLA MIESZKAŃCÓW GMINY*}

\section{PUBLIC TENDER AS A FORM OF SELECTION OF THE ELECTRICITY SUPPLIER FOR THE RESIDENTS OF THE COMMUNE}

DOI: $10.15611 / \mathrm{pn} .2018 .540 .04$

JEL Classification: K32

Streszczenie: Artykuł skoncentrowany jest na tematyce wykonywania zadań publicznych przez gminy w zakresie zapewnienia jej mieszkańcom dostawy energii. Gminy są odbiorcami energii elektrycznej. Jej zakupu dokonują w celu wykonywania powierzonych im zadań w zakresie zaspokojenia potrzeb mieszkańców wiążących się z elektrycznością. Ze względu na to, że gmina jest jednostką publiczną, zobowiązana jest dokonać zakupu energii, opierając się na transparentnych kryteriach, a więc w ramach procedury zamówień publicznych. Celem artykułu jest wskazanie, jakie kryteria gmina powinna uwzględnić, dokonując wyboru dostawcy energii, przy założeniu, że powinna ona uwzględnić nie tylko czynniki cenowe, ale również pozacenowe, zwłaszcza ochronę środowiska w toku wytwarzania energii przez przedsiębiorstwa energetyczne. W trakcie prac nad niniejszym artykułem wykorzystano metodę dogmatyczną przez analizę ustawodawstwa unijnego i polskiego.

Słowa kluczowe: przetarg publiczny, zasada TPA, energia elektryczna, gmina.

Summary: The article focuses on the performance of public tasks by communes in the scope of ensuring energy supply to its inhabitants. Communes are consumers of electricity. They purchase it in order to perform the tasks assigned to them in the scope of satisfying the inhabitants' needs in the field of electricity. Since the commune is a public entity, it is obliged to purchase energy on the basis of transparent criteria, i.e. within the framework of a public procurement procedure. The aim of the article is to indicate which criteria should be taken into account by the commune when choosing the energy supplier, with the assumption that it

* Artykuł powstał w ramach projektu badawczego SONATA BIS finansowanego ze środków Narodowego Centrum Nauki, na podstawie decyzji nr DEC-2014/14/E/HS5/00845, umowa nr UMO$-2014 / 14 / \mathrm{E} / \mathrm{HS} 5 / 00845$. 
should take into account not only price but also non-price factors, especially environmental protection during the generation of energy by energy companies. In the course of work on this article, the dogmatic method was used through the analysis of EU and Polish legislation.

Keywords: public tender, TPA principle, electricity, commune.

\section{Wstęp}

W Polce obowiązuje konstytucyjna zasada decentralizacji władzy publicznej, zgodnie z którą nastąpiło przeniesienie części uprawnień i odpowiedzialności władzy publicznej z organów władzy państwowej na organy władzy samorządowej możliwie najniższego szczebla ${ }^{1}$. Zgodnie $\mathrm{z}$ tą zasadą terytorium państwa podzielone jest na gminy $^{2}$, powiaty ${ }^{3}$ i województwa ${ }^{4}$. Podstawową jednostką samorządu terytorialnego jest gmina, której mieszkańcy tworzą z mocy prawa wspólnotę samorządową ${ }^{5}$. Do zakresu działania gminy należą wszystkie sprawy publiczne o znaczeniu lokalnym ${ }^{6}$, w tym głównie zadania, których wykonanie pozwala na zaspokojenie zbiorowych potrzeb mieszkańców gminy, takie jak m.in. sprawy z zakresu ochrony środowiska, gospodarki wodnej, dróg, ulic i mostów, zaopatrzenia w wodę, ochrony zdrowia, pomocy społecznej, wspierania rodziny, kultury fizycznej, porządku publicznego i bezpieczeństwa obywateli oraz ochrony przeciwpożarowej i przeciwpowodziowej, polityki prorodzinnej, w tym zapewnienia kobietom w ciąży opieki socjalnej, medycznej i prawnej, a także zaopatrzenia w energię elektryczną i cieplną oraz gaz?. Ostatnie z wymienionych zadań publicznych jest najistotniejsze w kontekście podjętego zagadnienia badawczego, bowiem zgodnie z obowiązującym w Polsce prawem gmina odpowiedzialna jest za zaopatrzenie mieszkańców w energię elektryczną ${ }^{8}$. Tym samym ustawodawca uczynił gminę lokalnym kreatorem polityki energetycz-

${ }^{1}$ Zob. art. 15 Konstytucji Rzeczypospolitej Polskiej z dnia 2 kwietnia 1997 r., Dz. U. nr 78 , poz. 483 ze zm. Szerzej: J. Korczak, Konstytucyjne podstawy struktury i funkcji samorzadu terytorialnego, [w:] Konstytucyjne podstawy funkcjonowania administracji publicznej. System prawa administracyjnego, tom 2, red. R. Hauser, A. Wróbel, Z. Niewiadomski, Warszawa 2012, s. 187 i n.

${ }^{2}$ Ustawa z dnia 8 marca 1990 r. o samorządzie gminnym, t. j. Dz. U. z 2018 r., poz. 994 ze zm.

${ }^{3}$ Ustawa z dnia 5 czerwca 1998 r. o samorządzie powiatowym, t. j. Dz. U. z 2018 r., poz. 995 ze zm.

${ }^{4}$ Ustawa z dnia 5 czerwca 1998 r. o samorządzie województwa, t. j. Dz. U. z 2018 r., poz. 1000 ze zm.

${ }^{5}$ Zob. art. 164 Konstytucji oraz art. 1 ustawy o samorządzie gminnym.

${ }^{6}$ Konstytucja ustanawia na rzecz gminy zasadę domniemania kompetencji, która chroni gminę przed wkraczaniem w jej zadania organów administracji rządowej lub organów jednostek samorządowych innych szczebli. Zob. B. Banaszak, Konstytucja Rzeczypospolitej Polskiej. Komentarz, wyd. 2, Warszawa 2012.

${ }^{7}$ Art. 7 ustawy o samorządzie gminnym.

${ }^{8}$ Zob. H. Wolska, Realizacja zadań publicznych przez spótkę komunalna w systemie zamówień publicznych, Warszawa 2018, s. 37-40. 
nej ${ }^{9}$ W tym zakresie gmina przede wszystkim: planuje i organizuje zaopatrzenie w energię, planuje oświetlenia miejsc publicznych i dróg znajdujących się na terenie gminy, finansuje oświetlenia ulic, placów i dróg publicznych znajdujących się na terytorium gminy oraz planuje i organizuje działania mające na celu racjonalizację zużycia energii i promocję rozwiązań zmniejszających zużycie energii na obszarze gminy ${ }^{10}$. Powyższe uwagi pozwalają na konstatację, iż gmina jest odbiorcą (kupującym) energii elektrycznej, z której następnie korzystają mieszkańcy gminy (głównie w obiektach użyteczności publicznej). Należy jednak mieć na uwadze, że gmina należy do jednostek sektora finansów publicznych ${ }^{11}$, co oznacza - w ogólnym rozumieniu - że wydatkować musi środki pieniężne (publiczne) w sposób transparentny. Transparentność wydatkowania środków pieniężnych przez gminy (i inne podmioty publiczne) zapewniają zasady prawne ustanowione w Ustawie z dnia 29 stycznia 2004 r. - Prawo zamówień publicznych ${ }^{12}$, o czym szczegółowo w dalszej części tekstu.

\section{Prawne i faktyczne zastosowanie zasady TPA (Third Party Access) przez gminy}

Jedną z ważniejszych rzeczy do omówienia, potrzebnych dla zrealizowania celu badawczego, jest ukazanie istoty zasady TPA obowiązującej w sektorze energetycznym, a następnie określenie faktycznych możliwości zastosowania tej zasady przez gminy. W Polsce z dniem 1 lipca 2007 r. nastąpiło otwarcie rynku energii elektrycznej na konkurencję, co potwierdzają przepisy ustawy Prawo energetyczne. Zgodnie z przepisami tej ustawy odbiorcy paliw gazowych lub energii mają prawo zakupu

\footnotetext{
${ }^{9}$ Dodać jednak trzeba, że planistyczne zadania gminy w omawianym zakresie determinowane są założeniami polityki energetycznej państwa oraz miejscowego planu zagospodarowania przestrzennego lub ustaleniami zawartymi w studium uwarunkowań i kierunków zagospodarowania przestrzennego gminy, a także odpowiednim programem ochrony powietrza przyjętym na podstawie art. 91 Ustawy z dnia 27 kwietnia 2001 r. - Prawo ochrony środowiska, t. j. Dz. U. z 2018 r., poz. 799 ze zm. Zob. art. 18 Ustawy z dnia 10 kwietnia 1997 r. - Prawo energetyczne, t. j. Dz. U. z 2018 r., poz. 755 ze zm. Szerzej: M. Kuliński (red.), Prawo energetyczne. Komentarz, Warszawa 2017, passim.

${ }^{10}$ Zob. art. 18 ustawy Prawo energetyczne. Zob. również: „Właściciel instalacji oświetleniowej służącej do wykonywania zadań gminy określonych w art. 18 ust. 1 pkt 2 ustawy Prawo energetyczne nie może ograniczać praw gminy do wyboru dostawcy energii elektrycznej" dostępne na https:// www.uzp.gov.pl/baza-wiedzy/interpretacja-przepisow/opinie-dotyczace-ustawy-pzp/inne/wlasciciel-instalacji-oswietleniowej-sluzacej-do-wykonywania-zadan-gminy-okreslonych-w-art.-18-ust.-1pkt-2-ustawy-prawo-energetyczne,-nie-moze-ograniczac-praw-gminy-do-wyboru-dostawcy-energiielektrycznej (dostęp: 20.02.2019 r.).

${ }^{11}$ Zob. art. 9 pkt 2 Ustawy z dnia 27 sierpnia 2009 r. o finansach publicznych, t. j. Dz. U. z 2017 r., poz. 2077 ze zm. Zob. również: M. Szydło, Prawna koncepcja zamówienia publicznego, Warszawa 2014, s. 49 i n.
}

${ }^{12}$ T. j. Dz. U. z 2018 r., poz. 1986 ze zm. 
tych paliw lub energii od wybranego przez siebie sprzedawcy ${ }^{13}$. Przepisy krajowe odzwierciedlają zatem regulacje prawa unijnego, prawo wyboru sprzedawcy zagwarantowała bowiem na poziomie unijnym Dyrektywa 2009/72/WE Parlamentu Europejskiego i Rady z dnia 13 lipca 2009 r. dotycząca wspólnych zasad rynku wewnętrznego energii elektrycznej i uchylająca dyrektywę 2003/54/WE ${ }^{14}$.

Zatem TPA to zasada pozwalająca na dostęp stron trzecich do rynku energii, dzięki której odbiorca końcowy może swobodnie wybierać dostawcę energii (wytwórcę lub pośrednika), który zaoferuje najlepszą cenę i warunki dostawy. Zgodnie z postanowieniami dyrektywy 2009/72/WE państwa członkowskie zapewniają wdrożenie systemu dostępu stron trzecich do systemu przesyłowego i dystrybucyjnego opartego na opublikowanych taryfach. System ten ma mieć zastosowanie do wszystkich uprawnionych odbiorców oraz ma być stosowany obiektywnie i bez dyskryminacji. Państwa członkowskie zobowiązane są zapewnić, aby taryfy lub metody stosowane do ich kalkulacji były zatwierdzane przed ich wejściem w życie, a także zostały opublikowane. Zgodnie z przepisami ustawy Prawo energetyczne przedsiębiorstwa zajmujące się przesyłaniem lub dystrybucją energii są obowiązane zapewnić wszystkim odbiorcom oraz przedsiębiorstwom zajmującym się sprzedażą energii, na zasadzie równoprawnego traktowania, świadczenie usług przesyłania lub dystrybucji energii. Operator systemu przesyłowego lub dystrybucyjnego może odmówić dostępu w sytuacji, gdy nie dysponuje niezbędnymi zdolnościami. Odmowa taka musi być jednak należycie uzasadniona na podstawie obiektywnych oraz uzasadnionych technicznie i gospodarczo kryteriów.

Realizacja zasady dostępu stron trzecich do infrastruktury energetycznej ma gwarantować istnienie konkurencji na rynku energii elektrycznej ${ }^{15}$. Zasada ta ma ułatwić odbiorcom końcowym zmianę dostawcy. Przedsiębiorstwa obowiązane są udostępniać swoje sieci dostawcom energii, dzięki czemu odbiorca ma większą możliwość wyboru sprzedawcy. Warunkiem niezbędnym do realizacji zasady dostępu stron trzecich do infrastruktury jest obowiązywanie zasady rozdziału usług. W sytuacji gdy właścicielami sieci przesyłowych i dystrybucji są te same podmioty, które dostarczają energię elektryczną, nie można mówić ani o niedyskryminującym, ani o równym dostępie stron trzecich do infrastruktury, a tym samym - o konkurencji na rynku. Instrumentem, którego funkcją jest oddzielenie od siebie działalności sieciowej w zakresie przysłania i dystrybucji od innych form działalności (szczególnie wytwarzania i sprzedaży), jest unbundling. W sektorze energetycznym doszło do

${ }^{13}$ Zob. art. 4j ustawy Prawo energetyczne. Więcej zob. M. Kajda, Prawo do zmiany sprzedawcy a ochrona praw konsumenta, [w:] Prawo konsumenckie w praktyce, red. M. Czarnecka, T. Skoczny, Warszawa 2016, s. 287 i n.

${ }^{14}$ Dz. Urz. UE L 211/55.

${ }^{15}$ Zob. m.in. J. Baehr, A. Stawicki, Rozważania wokół równoległego stosowania prawa konkurencji i instrumentów regulacyjnych, [w:] Ochrona konkurencji i konsumentów w Polsce i Unii Europejskiej (studia prawno-ekonomiczne), red. C. Banasiński, Urząd Ochrony Konkurencji i Konsumentów, Warszawa 2005, s. 144 i n. 
rozdzielenia rachunkowości (unbundling księgowy), rozdzielenia funkcjonalnego/ organizacyjnego (unbundling funkcjonalny), rozdzielenia prawnego (unbundling prawny) oraz rozdzielenia właścicielskiego (unbundling właścicielski) ${ }^{16}$. Oznacza to, że dla pełnej realizacji uprawnień przewidzianych w przepisach unijnych konieczne było przeprowadzenie wielu zmian, głównie w strukturze rynku energii elektrycznej. Przykładowo wyznaczono operatorów systemów przesyłowych, nastąpiło prawne i organizacyjne wyodrębnienie operatorów systemów dystrybucyjnych oraz przedsiębiorstw energetycznych zajmujących się obrotem energią elektryczną.

Powyższe świadczy o tym, że zakup energii elektrycznej i jej zużycie jest nierozerwalnie związane z jej przesyłem. Uprawniony odbiorca końcowy może jednak zrezygnować z dotychczasowej umowy i zawrzeć osobno: a) z dowolnym sprzedawcą energii umowę na zakup i zużycie energii elektrycznej, b) z operatorem systemu dystrybucyjnego umowę na dystrybucję energii elektrycznej. Zatem realizacja prawa do zmiany sprzedawcy przez gminy (jak również przez innych odbiorców) jest zagadnieniem szerokim, ponieważ - ze względu na wymóg unbundlingu - odbiorca energii musi zawrzeć, oprócz umowy o sprzedaż energii, także umowę na jej dystrybucję lub przesyłanie. Dostarczanie energii elektrycznej odbywa się bowiem po uprzednim przyłączeniu do sieci, na podstawie umowy sprzedaży i umowy o świadczenie usług przesyłania lub dystrybucji. Umowa sprzedaży i umowa o świadczenie usług przesyłania lub dystrybucji mogą być zawarte przez jednego odbiorcę z dwoma odrębnymi przedsiębiorstwami energetycznymi. Istnieje ponadto możliwość zawarcia umowy kompleksowej ${ }^{17}$. Umowa sprzedaży powinna zawierać co najmniej postanowienia określające: miejsce dostarczenia energii do odbiorcy i jej ilość w podziale na okresy umowne, moc umowną oraz warunki wprowadzania jej zmian, cenę lub grupę taryfową stosowane w rozliczeniach i warunki wprowadzania zmian tej ceny i grupy taryfowej, sposób prowadzenia rozliczeń, wysokość bonifikaty za niedotrzymanie standardów jakościowych obsługi odbiorców, odpowiedzialność stron za niedotrzymanie warunków umowy, okres obowiązywania umowy i warunki jej rozwiązania. Z kolei umowa o świadczenie usług przesyłania energii poza wymaganiami dla umowy sprzedaży energii elektrycznej musi dodatkowo zawierać postanowienia określające m.in.: standardy jakościowe, warunki zapewnienia niezawodności i ciągłości dostarczania paliw gazowych lub energii, sposób prowadzenia rozliczeń oraz parametry techniczne energii. Umowa kompleksowa może zawierać także postanowienia umowy sprzedaży energii, umowy o świadczenie usług przesyłania energii, zawartych przez sprzedawcę na rzecz i w imieniu odbiorcy końcowego z przedsiębiorstwem energetycznym zajmującym się przesyłaniem i dystrybucją energii elektrycznej. Ze względu na konieczność zachowania ciągłości dostaw umo-

${ }^{16}$ M. Szydło, Unbundling własnościowy (ownership unbundling) jako instrument regulacyjny w sektorze energetycznym, cz. I, Przegląd Ustawodawstwa Gospodarczego, 2007, nr 2, s. 3-5.

${ }^{17}$ M. Jaś-Nowopolska, Charakter prawny umowy kompleksowej w prawie energetycznym, Warszawa 2016, passim. 
wa z nowym sprzedawcą powinna wejść w życie w dniu wygaśnięcia umowy ze sprzedawcą dotychczasowym. W tym celu nowy sprzedawca jeszcze przed dniem rozpoczęcia sprzedaży energii elektrycznej ma obowiązek poinformować poprzedniego sprzedawcę o dniu rozpoczęcia przez niego sprzedaży energii.

W wyniku otwarcia ryku energii elektrycznej na polskim rynku energii elektrycznej, analogicznie jak to ma miejsce w krajach członkowskich UE, wzrosła dość znacznie liczba przedsiębiorstw zajmujących się obrotem energią elektryczną. Po takich zmianach, w wyniku których na rynku pojawiły się nowe podmioty zajmujące się obrotem energią elektryczną, gminy zobowiązane zostały do zakupu energii elektrycznej w trybie zamówień publicznych, przy czym nie mogą one w sposób swobodny korzystać z trybów przewidzianych przez ustawę Prawo zamówień publicznych, lecz zobligowane są, by stosować najbardziej konkurencyjny tryb udzielania zamówień publicznych, jakim jest przetarg, o czym szczegółowo poniżej.

\section{Wybór dostawcy energii w trybie udzielenia zamówienia publicznego na zakup energii przez gminę}

Z prawa wyboru dostawcy energii elektrycznej mogą skorzystać gminy. Świadczy to o tym, że mogą one dokonać wyboru sprzedawcy energii (czyli zmienić dotychczasowego sprzedawcę), kierując się potrzebami i interesem gminy, w tym interesem swoich mieszkańców. Odnosząc się ponadto do uwag zawartych w poprzednim punkcie, trzeba wyraźnie wskazać, że gmina ma możliwość wyboru sprzedawcy energii, brak jest jednak możliwości wyboru przedsiębiorstwa energetycznego zajmującego się świadczeniem usług dystrybucji bądź przesyłania energii elektrycznej, ponieważ przedsiębiorstwa te działają $\mathrm{W}$ obszarze tzw. monopolu naturalnego. W takiej sytuacji (tj. sytuacji prawno-faktycznej) wybór sprzedawcy energii elektrycznej powinien zostać dokonany przez zamawiającego w sposób zapewniający konkurencję, a więc w ramach przetargu nieograniczonego (tj. w którym może wziąć udział każde zainteresowane przedsiębiorstwo energetyczne zajmujące się obrotem energią). Z kolei podmiotem świadczącym usługi przesyłania i dystrybucji energii elektrycznej powinien być podmiot, do którego sieci przyłączone są nieruchomości należące do zamawiającego. W praktyce powyższą zasadę można zrealizować, udzielając zamówienia publicznego na sprzedaż energii elektrycznej w trybie przetargu nieograniczonego, natomiast umowę na dystrybucję energii do budynków zamawiającego zawrzeć można $\mathrm{z}$ wykonawcą wybranym w trybie zamówienia $\mathrm{z}$ wolnej ręki. A contrario oznacza to, że do zawarcia umowy sprzedaży energii elektrycznej nie będzie mogło być w ogóle wykorzystane zamówienie z wolnej ręki, ponieważ od 2007 r. rynek sprzedaży energii elektrycznej jest w pełni konkurencyjny, a to oznacza, że nie zajdzie przesłanka aktywująca ten sposób w postaci możliwości spełnienia świadczenia wyłącznie przez jednego wykonawcę z przyczyn technicznych o obiektywnym charakterze ${ }^{18}$. Umowa,

\footnotetext{
${ }^{18}$ Por. Wyrok WSA z 11 maja 2016 r., sygn. akt V SA/Wa 3974/15, Legalis, nr 1584836.
} 
na podstawie której dochodzi do zakupu energii elektrycznej, zostanie zakwalifikowana jako odpłatna umowa zawarta pomiędzy zamawiającym a wykonawcą, której przedmiotem będzie dostawa albo dostawa wraz z usługami.

Precyzując powyższy wątek, warto zatem wskazać, że użytkowanie energii elektrycznej jest możliwe na podstawie dwóch niezależnych umów (umowy sprzedaży i umowy o świadczenie usług dystrybucyjnych), stanowiących dwa odrębne przedmioty postępowań zamówieniowych, albo na podstawie jednej umowy, która łączy elementy tych dwóch wcześniej wskazanych umów, określanej mianem umowy kompleksowej, tj. umowy, którą łączy w sobie postanowienia umowy zarówno sprzedaży energii elektrycznej, jak i jej dystrybucji lub przesyłu ${ }^{19}$. Jeżeli gmina zdecyduje się na zawarcie umowy sprzedaży z przedsiębiorstwem obrotu, wówczas jest ona zobowiązana do zastosowania podstawowego trybu przetargowego, który z założenia zapewni konkurencyjność postępowania poszczególnym sprzedawcom i składanym przez nich ofertom. Natomiast zawarcie umowy o przesył energii elektrycznej z powodu monopolu naturalnego przedsiębiorstw sieciowych będzie uzasadniało zastosowanie zamówienia $\mathrm{z}$ wolnej ręki. Jeśli gmina zdecyduje się na usługę kompleksową, wówczas może powstać problem z prawidłową kwalifikacją zamówienia, w tym bowiem przypadku dojdzie do połączenia dwóch odmiennie traktowanych przedmiotów zamówienia publicznego: dostaw z usługami. Analizując ustawę Prawo zamówień publicznych, można dojść jednak do wniosku, że gdy zamówienie obejmuje równocześnie dostawy oraz usługi, to do udzielenia zamówienia stosuje się przepisy dotyczące tego przedmiotu zamówienia, którego wartościowy udział $\mathrm{w}$ danym zamówieniu jest największy. W zasadzie można uznać, że dostawa energii elektrycznej zawsze będzie miała większą wartość od usług pozwalających na korzystanie z niej, dlatego też w tym przypadku odpada tryb z wolnej ręki, a postępowanie w sprawie zawarcia tej umowy musi się odbywać zgodnie z zasadami przy zawieraniu umowy sprzedaży energii elektrycznej.

Obowiązek stosowania przez zamawiającego przepisów ustawy Prawo zamówień publicznych powstaje, gdy zamówienie przekroczy określoną wartość progową, która wynosi 30000 euro $^{20}$. Z tego powodu właściwy sposób określania przedmiotu zamówienia i szacowania jego wartości ma decydujący wpływ na ustalenie trybu zawarcia umowy. Jeśli wskazana kwota nie zostanie przekroczona, wówczas tryb zawarcia umowy będzie regulowany ustawą ogólną odnoszącą się do zasad zawierania umów (ustawa z dnia 23 kwietnia 1964 r. Kodeks cywilny ${ }^{21}$ ). Trudności we właściwym oszacowaniu wartości zamówienia na nabycie energii elektrycznej

${ }^{19}$ Zob. M. Swora, A. Falecki, Prawo energetyczne, tom I. Komentarz do art. 1-11s, red. M. Swora, Z. Muras, Warszawa 2016, s. 596 i n. Z kolei przykładowy opis przedmiotu zamówienia na sprzedaż i dystrybucję energii elektrycznej zob. A. Gawrońska-Baran, Opis przedmiotu zamówienia i SIWZ jako instrumenty w procesie przetargowym, Warszawa 2015, s. 96-97.

${ }^{20}$ Zob. art. 4 pkt 8 ustawy Prawo zamówień publicznych. Więcej na temat wyłączeń przedmiotowych zob. m. in. J. Pieróg, Prawo zamówień publicznych. Komentarz, Warszawa 2013, s. 39-54.

${ }^{21}$ T. j. Dz. U. z 2018 r., poz. 1025 z późn. zm. 
powoduje specyfika zapotrzebowania na to dobro. Interes zamawiającego (gminy) nie będzie bowiem zaspokojony w drodze jednorazowego świadczenia o ograniczonej wielkości, które pozwoli na użytkowanie tego dobra przez krótki czas. Ponadto w razie nieprzemyślanego zakupu energii elektrycznej i konieczności zawierania kolejnych umów sprzedaży energii elektrycznej zamawiający mógłby narazić się na zarzut uniknięcia stosowania przepisów ustawy przez dzielenie zamówienia na części. Istotą dostawy energii elektrycznej jest jej dostępność dla zamawiającego przez cały okres trwania umowy w ilościach niezbędnych dla wykonywanej działalności. $Z$ tego względu umowa sprzedaży energii elektrycznej będzie się różnić od sprzedaży innych dóbr, ponieważ cel zawarcia tej umowy zostanie zrealizowany wyłącznie przez regularny dostęp do tej energii, co prowadzi do konstrukcji zamówienia publicznego, którego przedmiotem są świadczenia powtarzające się okresowo. Na tej podstawie zamawiający w pierwszej kolejności będzie zobowiązany do ustalenia podstawy wartości zamówienia zgodnie z zasadami odnoszącymi się do oszacowania wartości tzw. zamówień okresowych ${ }^{22}$. W konsekwencji podstawą ustalenia wartości zamówienia na usługi lub dostawy powtarzające się okresowo jest, zgodnie z art. 34 ust. 1 ustawy Prawo zamówień publicznych, „łączna wartość zamówień tego samego rodzaju: 1) udzielonych w terminie poprzednich 12 miesięcy lub w poprzednim roku budżetowym, z uwzględnieniem zmian ilościowych zamawianych usług lub dostaw oraz prognozowanego na dany rok średniorocznego wskaźnika cen towarów i usług konsumpcyjnych ogółem albo 2) których zamawiający zamierza udzielić w terminie 12 miesięcy następujących po pierwszej usłudze lub dostawie". Przy tej okazji warto zatem wyraźnie podkreślić, że nie jest możliwe udzielenie zamówienia publicznego na zakup energii elektrycznej na czas nieoznaczony, co jest wyrazem popierania tendencji liberalizujących obrót energią elektryczną dokonujących się w prawie energetycznym ${ }^{23}$. Jednak umowa na sprzedaż energii elektrycznej nie powinna być zawarta na okres dłuższy niż cztery lata, chyba że zajdą ku temu odpowiednie okoliczności ${ }^{24}$. Precyzując tę kwestię, trzeba dodać, że zamawiający może zawrzeć umowę, której przedmiotem są świadczenia okresowe lub ciągłe, na okres dłuższy niż cztery lata, jeżeli wykonanie zamówienia w dłuższym okresie spowoduje oszczędności kosztów realizacji zamówienia w stosunku do okresu czteroletniego lub jest to uzasadnione zdolnościami płatniczymi zamawiającego lub zakresem planowanych nakładów oraz okresem niezbędnym do ich spłaty.

Gmina (jako zamawiający) zobowiązana jest do wyboru najkorzystniejszej ekonomicznie dla siebie oferty. Zobowiązuje ją do tego prawo unijne zawarte przede wszystkim w Dyrektywie Parlamentu Europejskiego i Rady 2014/24/UE z dnia 26 lutego 2014 r. w sprawie zamówień publicznych, uchylającej dyrektywę

${ }^{22}$ Zob. J. Jarnicka, Prawo zamówień publicznych. Komentarz, red. M. Jaworska, Warszawa 2018, s. 307-309.

${ }^{23} \mathrm{Na}$ temat źródeł i przesłanek liberalizacji sektora elektroenergetycznego zob.: M. Swora, Z. Muras, Prawo energetyczne. Komentarz, Warszawa 2010, s. 47-59.

${ }^{24}$ Zob. art. 34 ust. 3a ustawy Prawo zamówień publicznych. 
2004/18/WE ${ }^{25}$. Zgodnie z art. 67 ust. 2 lit. 6 wskazanej dyrektywy ofertę najkorzystniejszą ekonomicznie z punktu widzenia instytucji zamawiającej określa się na podstawie ceny lub kosztu, z wykorzystaniem podejścia opartego na efektywności kosztowej, takiego jak rachunek kosztów cyklu życia. Z kolei zgodnie z art. 68 dyrektywy 2014/24/UE może ona obejmować najlepszą relację jakości do ceny, którą szacuje się na podstawie kryteriów obejmujących aspekty jakościowe, środowiskowe lub społeczne związane z przedmiotem danego zamówienia publicznego ${ }^{26}$. Z zacytowanych przepisów wynika, że przy wyborze oferty zamawiający poza ceną musi uwzględnić kryteria pozacenowe, ale również zobowiązany jest wziąć pod uwagę rachunek kosztów cyklu życia. Zgodnie z pkt 96 preambuły do dyrektywy 2014/24/UE pojęcie rachunku kosztów cyklu życia oznacza wszystkie koszty ponoszone w trakcie cyklu życia robót budowlanych, dostaw lub usług. Obejmuje koszty wewnętrzne, ponoszone przez zamawiających lub innych użytkowników, takie jak koszty badań, rozwoju, produkcji, transportu, użytkowania, konserwacji i utylizacji. Ponadto rachunek kosztów cyklu życia może obejmować koszty przypisane ekologicznym efektom zewnętrznym, w tym koszty zanieczyszczenia spowodowane wydobywaniem surowców wykorzystywanych w produkcie lub spowodowane przez sam produkt lub jego wytworzenie, o ile ich wartość pieniężną można określić i zweryfikować. Innymi słowy, rachunek cyklu życia uwzględnia cztery grupy kosztów, a mianowicie: 1) koszty związane $\mathrm{z}$ nabyciem produktu (przede wszystkim cenę, ale też inne koszty, np. finansowania), 2) koszty związane z użytkowaniem - wydatki związane z eksploatacją produktu (np. zużycie energii, wody lub paliwa), oraz 3) koszty utrzymania - wydatki, które wiążą się z zapewnieniem gotowości urządzenia czy obiektu do użytkowania, np. koszty remontów, napraw, ubezpieczenia czy zarządzania, oraz 4) koszty związane z wycofaniem z eksploatacji, czyli np. koszty recyklingu lub złomowania ${ }^{27}$.

Regulacje prawa unijnego prowadzą zatem do ogólnej konstatacji, że ofertą najkorzystniejszą ekonomicznie jest ta, która przedstawia najkorzystniejszy bilans ceny i innych kryteriów odnoszących się do przedmiotu zamówienia publicznego albo oferta z najniższą ceną. Gmina wybiera ofertę najkorzystniejszą na podstawie kryteriów oceny ofert określonych w specyfikacji istotnych warunków zamówienia. Kryteriami oceny ofert są cena albo cena i inne kryteria odnoszące się do przedmio-

${ }^{25}$ Dz. Urz. UE L 94/65.

${ }^{26} \mathrm{~W}$ tym miejscu trzeba szczególnie podkreślić, że ustawodawca unijny uwzględnił aspekty środowiskowe, które muszą być wzięte pod uwagę w ramach oceny złożonych ofert w postępowaniu o udzielenie zamówienia publicznego. Prawodawca unijny nie wskazał bowiem jedynie kosztów mogących ustalić stricte ekonomiczną wartość zakupu usług (produktu, robót), ale także zewnętrzne koszty środowiskowe (o ile można określić i zweryfikować ich wartość pieniężną). Zob. W. Hartung, M. Bagłaj, T. Michalczyk, M. Wojciechowski, J. Krysa, K. Kuźma, Dyrektywa 2014/24/UE w sprawie zamówień publicznych. Komentarz, Warszawa 2015, s. 671.

${ }^{27}$ Zob. m.in. J. Pawelec, Dyrektywa 2014/24/WE w sprawie zamówień publicznych, Warszawa 2015, s. 321-322. 
tu zamówienia, szczególnie jakość, funkcjonalność, parametry techniczne, aspekty środowiskowe, społeczne, innowacyjne, serwis, termin wykonania zamówienia oraz koszty eksploatacji. W świetle powyższego należy stwierdzić, iż cena jest obligatoryjnym, lecz nie jednym kryterium oceny ofert, którym może posłużyć się zamawiający przy wyborze oferty najkorzystniejszej. Obok ceny zamawiający powinien co do zasady zastosować także inne kryteria odnoszące się do przedmiotu zamówienia. Pamiętać przy tym trzeba, że to sam zamawiający decyduje o zastosowaniu określonych kryteriów oceny ofert, kierując się specyfiką przedmiotu zamówienia oraz potrzebą uzyskania zamówienia na najkorzystniejszych warunkach. Określone przez zamawiającego kryteria oceny ofert winny odnosić się do przedmiotu zamówienia. Oznacza to, iż zamawiający nie może stosować dowolnych kryteriów oceny ofert, lecz tylko takie, które dotyczą oferowanej usługi. $Z$ drugiej strony, należy zauważyć, że kryteria oceny ofert nie mogą dotyczyć właściwości wykonawcy, a zwłaszcza jego wiarygodności ekonomicznej, technicznej lub finansowej. W tym zakresie mamy zatem do czynienia z ograniczeniem swobody zamawiającego co do możliwości dowolnego określania kryteriów oceny ofert ${ }^{28}$.

W zakresie omawianego tematu zauważyć trzeba, że kryterium pozacenowym, którym powinna kierować się gmina, wybierając ofertę na zakup energii elektrycznej, jest kryterium źródła wytwarzania energii elektrycznej ze źródeł odnawialnych. Kryterium takie wpisuje się $\mathrm{w}$ ogólne kryterium pozacenowe, jakim są aspekty środowiskowe. Stawiając wymóg wytarzania energii elektrycznej w źródłach odnawialnych ${ }^{29}$, gminy mogą stać się jednocześnie podmiotem promującym wzrost wytwarzania energii elektrycznej ze źródeł odnawialnych. Kryterium pozacenowe, polegające na promowaniu energii odnawialnej przy wyborze dostawcy energii dla gminy, wpisuje się w powszechny nakaz wzrostu wytwarzania energii elektrycznej ze źródeł odnawialnych w każdym państwie członkowskim UE ustanowiony w Dyrektywie Parlamentu Europejskiego i Rady 2009/28/WE z dnia 23 kwietnia 2009 r. w sprawie promowania stosowania energii ze źródeł odnawialnych zmieniającej i w następstwie uchylającej dyrektywy 2001/77/WE oraz 2003/3/WE ${ }^{30}$. Wskazana

${ }^{28}$ Wynika to z unijnej zasady równego traktowania wykonawców w systemie zamówień publicznej. Więcej na temat tej zasady zob.: T. Filipowicz, Zasada równego traktowania wykonawców w zamówieniach publicznych dotyczących technologii informatycznych, Warszawa 2015, s. 111 i n.

${ }^{29}$ Powszechnie przyjmuje się, że stosując kryterium pozacenowe w postaci aspektów środowiskowych, zamawiający może wziąć pod uwagę np. sprawność energetyczną dostarczanego sprzętu czy też trwałość produktu, wpływ na środowisko (np. przez wykazanie, że sam etap produkcji nie wpływa negatywnie na środowisko naturalne), czy ilość odpadów, które powstaną w wyniku eksploatacji urządzenia. Dodać przy tym również trzeba, że zamawiający zawsze też powinien mieć na względzie minimalizację ryzyka niekorzystnego oddziaływania na środowisko już w trakcie wykonywania zamówienia, tj. powinien utrwalać i inicjować zachowania proekologiczne, co przełoży się nie tylko na zwiększenie efektywności udzielanych zamówień, ale i ograniczy niekorzystne wpływy na środowisko naturalne. Zob.: E. Grabowska-Szweicer, M. Saczywsko, Wybór najkorzystniejszej oferty w postępowaniu o udzieleniu zamówienia publicznego, Wrocław 2017, s. 62.

${ }^{30}$ Dz. Urz. UE L 140/16. 
dyrektywa obliguje państwa członkowskie do osiągnięcia określonego wzrostu wytwarzania energii elektrycznej ze źródeł odnawialnych w odniesieniu do 2020 r. $^{31}$ Gminy, jako element państwa, również powinny czuć się współodpowiedzialne za wykonanie obowiązków ustanowionych prawem unijnym. Nie ma wątpliwości, że kiedy ogłaszany jest przetarg na zakup energii elektrycznej dostarczanej do gminy, wprowadzenie kryterium wytwarzania tej energii w źródłach odnawialnych z jednoczesnym uzasadnieniem korzystnej oceny oferty przedsiębiorstwa energetycznego, które będzie dostarczało energię do gminy wytwarzaną (w określonym zakresie) ze źródeł odnawialnych, stawia takie gminy jednocześnie w roli podmiotu promującego wytwarzanie energii elektrycznej w źródłach odnawialnych ${ }^{32}$. Jednocześnie takie działanie gminy jest spójne w regulacjami prawa unijnego. Przy tym wprowadzenie aspektów środowiskowych jako kryteriów oceny ofert sprzyja ograniczeniu degradacji środowiska naturalnego. Tym samym kryterium wytwarzania energii elektrycznej ze źródeł odnawialnych przyczyni się do wymiernych oszczędności finansowych, bowiem państwa zaoszczędzą - na przyszłość - wydatkowanie środków publicznych na poprawę środowiska. Wyraźnie podkreślić trzeba, że gmina musi określić, jakie znaczenie przy ocenie ofert przedsiębiorstw energetycznych będzie miało kryterium wytwarzania energii elektrycznej ze źródeł odnawialnych ${ }^{33}$. W tym zakresie każdy zamawiający, również gmina, ustala liczbę procentową dla każdego z kryteriów, przy założeniu, że wszystkie kryteria łącznie stanowią 100\% ${ }^{34}$.

\section{Zakończenie}

Wprowadzenie zasady TPA w sektorze energetycznym i umożliwienie podmiotom zmiany sprzedawcy energii elektrycznej jest korzystnym rozwiązaniem prawnym, które może odbiorcom energii elektrycznej przysporzyć wymiernych korzyści ekonomicznych. Odbiorcy ci bowiem mogą zdecydować, z usług którego dostawcy chcą korzystać. Zasada ta jest jednakowa, jeżeli chodzi zarówno o odbiorców indy-

${ }^{31}$ Dyrektywa stawia poszczególnym państwom członkowskim indywidualnie określone cele. Polska zobligowana jest osiągnąć do 2020 r. 15-procentowy udział energii elektrycznej ze źródeł odnawialnych w końcowym zużyciu energii brutto. Zob. załącznik nr I do dyrektywy 2009/28/WE. Zob. również: R. Mędrzycki, Odnawialne źródła energii w aspekcie zrównoważonego rozwoju - zarys problematyki, [w:] Tworzenie i wykorzystanie energii ze źródet odnawialnych (OZE). Problemy administracyjno-prawne, Warszawa 2016, s. 9-23.

32 Zob. K. Martowłos, Zielone zamówienia publiczne w energetyce, [w:] Państwo a gospodarka. Instrumenty prawne realizacji zamówień publicznych, Toruń 2015, s. 223-237.

${ }^{33}$ Innymi słowy gmina jako zamawiający, stosując kryteria środowiskowe (w tym pierwszeństwo wyboru ofert wytwórców produkujących energię elektryczną ze źródeł odnawialnych), musi określić zarówno w ogłoszeniu o zamówieniu, jak i w specyfikacji istotnych warunków zamówienia liczbę punktów oraz sposób ich przyznawania za konkretne kryterium. Zob. E. Grabowska-Szweicer, M. Saczywsko, wyd. cyt., s. 63.

${ }^{34}$ K. Różowicz, N. Gazecka, Zamówienia publiczne na dostawy i ustugi IT. Wybrane zagadnienia praktyczne, Warszawa 2016, s. 164. 
widualnych, jak i o odbiorców należących do sektora publicznego, jak na przykład gminy, które odpowiedzialne są za dostarczanie energii elektrycznej swoim mieszkańcom i zapewnienie tym samym ciągu w dostawie energii elektrycznej głównie w budynkach użyteczności publicznej. Przed przystąpieniem do procedury zmiany sprzedawcy, gmina powinna jednak przede wszystkim zbudować system monitorowania zużycia energii elektrycznej oraz wielkości dostaw, a także dokonać analizy umów w zakresie mocy umownych. Musi ponadto sporządzić bazę użytkowanych przez nią obiektów, w której znajdą się m.in. informacje o danych technicznych budynków oraz rodzaju prowadzonej w niej działalności. Analiza profilu zużycia energii w poszczególnych budynkach użyteczności publicznej będzie pomocna przy przygotowaniu dokumentacji przetargowej. Jak wynika bowiem z przeprowadzonych badań, gmina może $\mathrm{w}$ pełni skorzystać $\mathrm{z}$ dostępnego prawa $\mathrm{w}$ zakresie zmiany sprzedawcy energii elektrycznej, niemniej jednak, ze względu na to, że należy do kategorii podmiotów publicznych (wydatkujących finanse publiczne), zobligowana jest przeprowadzić publiczny przetarg na wybór sprzedawcy energii elektrycznej. Nie ma wątpliwości co do tego, że przy wyborze nowego sprzedawcy energii elektrycznej gmina kieruje się chęcią zmniejszenia wydatków związanych z zakupem energii elektrycznej, niemniej jednak - mając na uwadze prawo unijne - zobowiązana jest uwzględnić także inne czynniki kosztowe, jak również kryteria pozacenowe. W tym ostatnim wymiarze musi uwzględniać unijną politykę klimatyczną i korzystnie ocenić oferty tych sprzedawców, którzy na obszarze gminy będą dostarczać energię wytworzoną w źródłach odnawialnych.

\section{Literatura}

Baehr J., Stawicki A., Rozważania wokół równoległego stosowania prawa konkurencji i instrumentów regulacyjnych, [w:] Ochrona konkurencji i konsumentów w Polsce i Unii Europejskiej (studia prawno-ekonomiczne), red. C. Banasiński, Urząd Ochrony Konkurencji i Konsumentów, Warszawa 2005.

Banaszak B., Konstytucja Rzeczypospolitej Polskiej. Komentarz, wydanie 2, Warszawa 2012.

Filipowicz T., Zasada równego traktowania wykonawców w zamówieniach publicznych dotyczacych technologii informatycznych, Wydawnictwo Wolters Kluwer, Warszawa 2015.

Gawrońska-Baran A., Opis przedmiotu zamówienia i SIWZ jako instrumenty w procesie przetargowym, C.H. Beck, Warszawa 2015.

Grabowska-Szweicer E., Saczywko M., Wybór najkorzystniejszej oferty w postępowaniu o udzieleniu zamówienia publicznego, Presscom, Wrocław 2017.

Hartung W., Bagłaj M., Michalczyk T., Wojciechowski M., Krysa J., Kuźma K., Dyrektywa 2014/24/ UE w sprawie zamówień publicznych. Komentarz, C. H. Beck, Warszawa 2015.

Jarnicka J., Prawo zamówień publicznych. Komentarz, red. M. Jaworska, C.H. Beck, Warszawa 2018.

Jaś-Nowopolska M., Charakter prawny umowy kompleksowej w prawie energetycznym, Difin, Warszawa 2016.

Kajda M., Prawo do zmiany sprzedawcy a ochrona praw konsumenta, [w:] Prawo konsumenckie w praktyce, red. M. Czernecka, T. Skoczny, Warszawa 2016. 
Korczak J., Konstytucyjne podstawy struktury i funkcji samorzadu terytorialnego, [w:] Konstytucyjne podstawy funkcjonowania administracji publicznej. System prawa administracyjnego, tom 2, red. R. Hauser, A. Wróbel Z., Niewiadomski, Warszawa 2012.

Kuliński M. (red.), Prawo energetyczne. Komentarz, C.H. Beck, Warszawa 2017.

Martowłos K., Zielone zamówienia publiczne w energetyce, [w:] Państwo a gospodarka. Instrumenty prawne realizacji zamówień publicznych, Wydawnictwo KNPPG, Torun 2015.

Mędrzycki R., Odnawialne źródta energii w aspekcie zrównoważonego rozwoju-zarys problematyki, [w:] Tworzenie $i$ wykorzystanie energii ze źródet odnawialnych (OZE). Problemy administracyjno-prawne, Wydawnictwo Uniwersytetu Kardynała Stefana Wyszyńskiego, Warszawa 2016, s. 9-23.

Pawelec J., Dyrektywa 2014/24/WE w sprawie zamówień publicznych, C.H. Beck, Warszawa 2015.

Pieróg J., Prawo zamówień publicznych. Komentarz, C.H. Beck, Warszawa 2013.

Różowicz K., Gazecka N., Zamówienia publiczne na dostawy i ustugi IT. Wybrane zagadnienia praktyczne, Wolters Kluwer, Warszawa 2016.

Swora M., Falecki A., Prawo energetyczne, t I. Komentarz do art. 1-11s, red. M. Swora, Z. Muras, Warszawa 2016.

Swora M., Muras Z., Prawo energetyczne. Komentarz, Wolters Kluwer, Warszawa 2010.

Szydło M., Prawna koncepcja zamówienia publicznego, C.H. Beck, Warszawa 2014.

Szydło M., Unbundling własnościowy (ownership unbundling) jako instrument regulacyjny w sektorze energetycznym, cz. I, Przegląd Ustawodawstwa Gospodarczego, 2007, nr 2.

Wolska H., Realizacja zadań publicznych przez spótkę komunalną w systemie zamówień publicznych, C.H. Beck, Warszawa 2018.

\section{Akty prawne i orzecznictwo}

Konstytucja Rzeczypospolitej Polskiej z dnia 2 kwietnia 1997 r., Dz. U. nr 78, poz. 483 ze zm. Ustawa z dnia 8 marca 1990 r. o samorządzie gminnym, t. j. Dz. U. z 2018 r., poz. 994 ze zm. Ustawa z dnia 10 kwietnia 1997 r. - Prawo energetyczne, t. j. Dz. U. z 2018 r., poz. 755 ze zm. Ustawa z dnia 5 czerwca 1998 r. o samorządzie powiatowym, t. j. Dz. U. z 2018 r., poz. 995 ze zm. Ustawa z dnia 5 czerwca 1998 r. o samorządzie województwa, t. j. Dz. U. z 2018 r., poz. 1000 ze zm. Ustawa z dnia 27 kwietnia 2001 r. - Prawo ochrony środowiska, t. j. Dz. U. z 2018 r., poz. 799 ze zm. Ustawa z dnia 27 sierpnia 2009 r. o finansach publicznych, t. j. Dz. U. z 2017 r., poz. 2077 ze zm. Wyrok WSA z 11 maja 2016 r., sygn. Akt V SA/Wa 3974/15, Legalis nr 1584836. 